\title{
Spatial-temporal distribution and recruitment of Stramonita haemastoma (Linnaeus, 1758) (Mollusca) on a sandstone bank in Ilhéus, Bahia, Brazil
}

\author{
Santos, JJB.* and Boehs, G.* \\ Programa de Pós-graduação em Zoologia, Departamento de Ciências Biológicas, \\ Universidade Estadual de Santa Cruz - UESC, Rod. Ilhéus-Itabuna, Km 16, CEP 45650-900, Ilhéus, BA, Brazil \\ *e-mail: josimaribiologia@yahoo.com.br; gboehs@uesc.br
}

Received May 3, 2010 - Accepted November 8, 2010 - Distributed November 30, 2011

(With 4 figures)

\begin{abstract}
We examined aspects of the population ecology of the gastropod Stramonita haemastoma at Ilhéus, Bahia, Brazil. We collected monthly from October 2007 through September 2008 on a sandstone bank $1.5 \mathrm{~km}$ long, on which two points and two sampling levels were defined. We took five previously randomised replicates at each level, using a square enclosing an area of $0.0625 \mathrm{~m}^{2}$. The snails were photographed, counted, and measured at the site. Both recruits and other individuals in the population preferentially inhabit the regions closer to the lower shore, where they are submerged for longer periods and are less subject to physiological stresses caused by temperature variation and desiccation. The cracks and holes in the bank serve as refuges and places for S. haemastoma to lay their egg capsules. Recruits were observed throughout the study period, and the population showed continuous reproduction.
\end{abstract}

Keywords: ecology, gastropod, intertidal, macrobenthos.

\section{Distribuição espaço-temporal e recrutamento de Stramonita haemastoma (Linnaeus, 1758) (Mollusca) em um banco arenítico de Ilhéus, Bahia, Brasil}

\begin{abstract}
Resumo
Neste estudo objetivou-se analisar aspectos da ecologia populacional do gastrópode Stramonita haemastoma em Ilhéus (Bahia). As amostragens foram realizadas mensalmente, entre outubro de 2007 e setembro de 2008, em um banco arenítico com 1,5 km de extensão, no qual foram estabelecidos dois pontos e dois níveis amostrais. Em cada nível foram feitas cinco repetições previamente aleatorizadas, utilizando-se um delimitador quadrado com $0,0625 \mathrm{~m}^{2} \mathrm{de}$ área. Os animais foram fotografados, quantificados e mensurados no local. Foi evidenciado que tanto recrutas quanto os demais indivíduos da população habitam preferencialmente as faixas mais próximas do infralitoral, onde, em função do maior tempo de submersão, os animais ficam menos sujeitos a estresses fisiológicos decorrentes de variação térmica e dessecação. Por apresentarem fendas e buracos, esses locais servem ainda de refúgio e ambiente para posturas de S. haemastoma. Foram observados recrutas ao longo de todo o período, evidenciando reprodução contínua.
\end{abstract}

Palavras-chave: ecologia, gastrópode, entremarés, macrobentos.

\section{Introduction}

The Florida rocksnail Stramonita haemastoma (Linnaeus, 1758) (Mollusca: Thaididae), a species of oyster drill, occurs in the Americas from North Carolina to Florida, Texas, northern South America, and along the coasts of Brazil and Uruguay (Rios, 2009). It is abundant in rocky intertidal zones, inhabiting preferentially the middle (Ramirez et al., 2009) and subtidal levels (Rilov et al., 2001). It can be found on oyster reefs, submerged wrecks, and buoys in these regions (Thomé et al., 2004).

According to Butler (1985), this snail should be extremely successful in that it has no known natural predators in adulthood. However, the drills become damaged by commensals residing in and gradually eroding their

hosts' shells. Stramonita haemastoma has a broad diet, preying on mussels and other shellfish such as Perna perna (Linnaeus, 1758) (Mytilidae) and Crassostrea rhizophorae (Guilding, 1828) (Ostreidae), besides crustaceans such as Chthamalus bisinuatus (Pilsbry, 1916) and Tetraclita stalactifera (Lamarck, 1818) (Duarte and Holler, 1987) and the colonial polychaete Phragmatopoma lapidosa (Kimberg, 1867) (Watanabe and Young, 2006). The prey may vary depending on the locale. In the absence of the normal food supply, the drill readily feeds on its companions (Butler, 1985).

Safriel et al. (1980) stated that in observations conducted in the 1960s and 1970s, this species appeared to have affected 
the distribution of mussel beds of the indigenous species Mytilaster minimus (Poli, 1795). The fact that S. haemastoma includes some economically exploited bivalves in its diet maximises the importance of understanding its ecological relationships. According to D'Asaro (1966) and Roller and Stickle (1988), this species can cause serious damage in oyster-growing areas. Stramonita haemastoma is one of the top predators of oysters and mussels in shellfish aquaculture facilities on the coast of Santa Catarina, Brazil (Ferreira and Magalhães, 2004; Nascimento and Pereira, 2004; Poli, 2004). On the other hand, it serves as food and subsistence for coastal communities in some parts of the Brazilian coast.

The sandstone banks consist of sands with $20 \%$ to $80 \%$ quartz, with the remainder composed of carbonate fragments, especially of shellfish and algae (Mabesoone, 1964). This study was conducted on a sandstone bank located in Ilhéus, on the southern coast of the state of Bahia. It is situated in the perimeter of the city of Ilhéus, the region is subject to various human impacts, such as dumping of untreated domestic sewage, fishing and recreational activities. We observed in a pilot study the presence of representatives of Porifera, Cnidaria, Anellida, Mollusca, Crustacea, Echinodermata and Chordata, and several species of algae, notably the predominance of green algae. We also observed that this area contains species of great ecological and economic importance, for example, sea urchins, lobsters, crabs, and fishes. The most abundant species are the molluscs Brachidontes solisianus (Orbigny, 1846) and Littorina ziczac (Gmelin, 1791), the crustacean Chthamalus bisinuatus (Pilsbry, 1916), and the echinoderm Echinometra lucunter (Linnaeus, 1758). Stramonita haemastoma is one of the most conspicuous species. The present study aimed to analyse the spatial and temporal distribution of this species in this location, assessing possible correlations with variations in temperature, salinity, and rainfall. We also investigated the occurrence of preferential time periods and stretches of bank for recruitment of the species in the region, and inventoried the macrobenthic species present near of S. haemastoma.

\section{Materials and Methods}

The study was conducted on a sandstone bank in Ilhéus, southern Bahia. The bank is about $1.5 \mathrm{~km}$ long and between 5 and $10 \mathrm{~m}$ wide. Along the bank are two distinct bands of occupation, the upper composed predominantly of the barnacle Chthamalus bisinuatus and the mussel Brachidontes solisianus, and another closer to sea level, mainly the sea urchin Echinometra lucunter. We selected two sampling points (P) for this study. P1 (14 48' 89' S, $39^{\circ} 01$ ' $\left.44^{\prime \prime} \mathrm{W}\right)$ and P2 (14 ${ }^{\circ} 48^{\prime} 55^{\prime}$ ' S, 39 $01^{\circ}$ ' $\left.44^{\prime \prime} \mathrm{W}\right)$ were $1 \mathrm{~km}$ apart, and $\mathrm{P} 2$ was slightly higher than P1 with respect to sea level. For each point, two sampling levels were selected (N1, lower and N2, upper), $7 \mathrm{~m}$ apart. N1 and N2 were respectively, the end of the sandstone bank nearest to and farthest from the lower shore, so that the samples were taken in locations with different periods of exposure (Figure 1). Five previously randomised sampling points were delimited at each level. Sampling was conducted at monthly intervals from October 2007 through September 2008. As the delimiter, we used a square with each side measuring $25 \mathrm{~cm}$ (Area: $0.0625 \mathrm{~m}^{2}$ ) (Foster et al., 1991). The location measurements were made using a tapeline. The individual drills were photographed, counted, and measured for height ( $\mathrm{mm})$, taken as the distance between the apex and the lower edge of the shell (Lindner, 1983), using a digital caliper. All animals were returned to their habitat after the measurements. As evidence of recruitment, we also observed the occurrence of laying (egg capsules) and the presence of juveniles in the months following the laying events. In addition, we recorded instances of macrobenthic species interacting with S. haemastoma. When necessary, some specimens of these species were collected for identification in the laboratory.

The temperature and salinity of the seawater near the holes of S. haemastoma were measured monthly during each sampling foray, using a standard mercury thermometer and a manual optical refractometer. We also measured the temperature and salinity in microhabitats (holes) of $S$. haemastoma over three days at low tide. The rainfall data were obtained from the records of the Climatological Station of CEPLAC - Executive Committee of the Cocoa Farming Plan. The fieldwork was conducted in daytime during low tide.

The Shapiro-Wilk test was used to determine the normal distribution of the data, which were previously transformed by $\log (\mathrm{x}+1)$. To test the significance of differences in the numbers of individuals over the sampling period (temporal distribution) and between points and levels (spatial distribution), we used a multifactorial analysis of variance (ANOVA) $(\alpha=0.05)$. The a posteriori Tukey test was used to compare means between treatments that were significantly different $(\mathrm{p}<0.05)$. To assess recruitment periods, we constructed histograms for the size and height

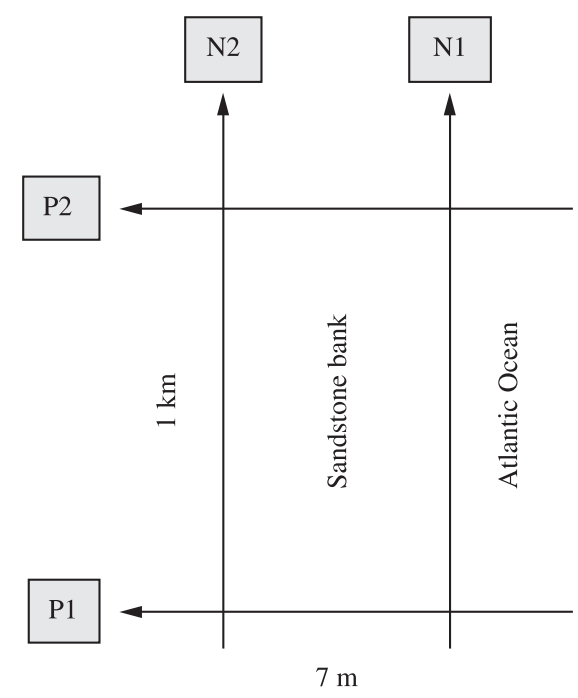

Figure 1. Sampling design of the study. 
of the specimens. The density in relation to abiotic factors (temperature, salinity, and rainfall) was assessed using the Pearson correlation analysis.

\section{Results}

The temperature of seawater adjacent to the sandstone bank ranged between $21-29^{\circ} \mathrm{C}$ (mean $26^{\circ} \mathbf{C}, \mathrm{SD} \pm 1.6$ ) and salinity 33-37 (mean 35.3, $\mathrm{SD} \pm 0.7$ ). In microhabitats, the temperature ranged between $24-25{ }^{\circ} \mathrm{C}$ at the lower level and $24-29{ }^{\circ} \mathrm{C}$ at the upper level of both locations. The salinity was the same in both $\mathrm{N} 1$ and N2 of point P1 (35.5-36), and in N1 and N2 of P2 (36-39). The heaviest rainfall occurred in November 2007 (131 mm), March $(252.5 \mathrm{~mm})$, and June $(113.2 \mathrm{~mm})$ of 2008 . The least rainfall occurred in May $(27.5 \mathrm{~mm})$ and in September (4 mm) of 2008 (Figure 2).

We analysed 2080 specimens of S. haemastoma. Significant differences $(\rho<0.05)$ in abundance occurred between points, levels, and sampling months (Table 1). The mean number of individuals was 167 ind. $\mathrm{m}^{-2}(\mathrm{SD} \pm 9)$ in $\mathrm{P} 1$, and 109 ind. $\mathrm{m}^{-2}(\mathrm{SD} \pm 6)$ in $\mathrm{P} 2 . \mathrm{N} 1$, which was closer to the lower shore, had a mean of 162 ind. ${ }^{-2}(\mathrm{SD} \pm 9)$ and $\mathrm{N} 2$ of 114 ind. $\mathrm{m}^{-2}(\mathrm{SD} \pm 7)$. The lowest abundances $(\rho<0.05)$ of $S$. haemastoma occurred in October 2007 and August 2008. During these months, the numbers of

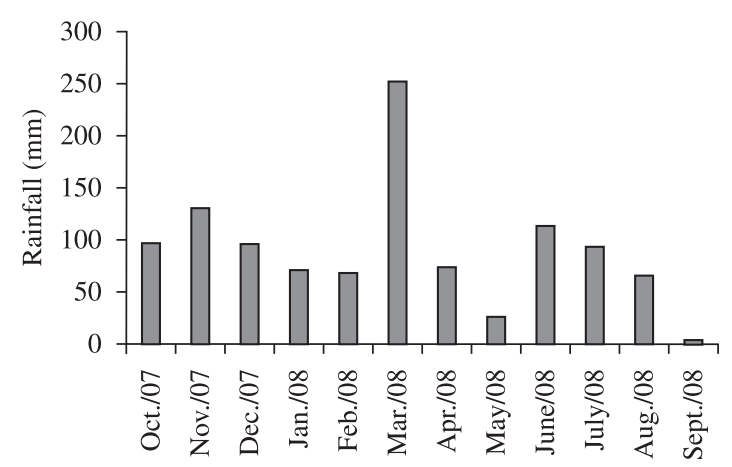

Figure 2. Rainfall in Ilhéus, Bahia during the sampling period (October 2007 through September 2008). recruits were also low. The highest abundance occurred during summer, in February 2008. Density and salinity were positively correlated $(r=0.35$ for the adjacent water, and 0.4 for water in the microhabitats).

The size-frequency histograms showed that recruitment occurred throughout the study period (Figures 3 and 4). Recruitment was predominant in the $\mathrm{N} 1$, closer to the lower shore, especially in the $\mathrm{N} 1$ of $\mathrm{P} 1$, where recruits were observed during the entire period. The most significant recruitment in this level occurred in July 2008 (Figure 3). There was also conspicuous egg-laying (egg capsules) in this level. The site with the lowest recruitment frequency was the $\mathrm{N} 2$ of $\mathrm{P} 2$, where there was no recruitment in several months (Figure 4).

Eleven species were near S. haemastoma, and nine of them were recorded in all months. These species include representatives of the phyla Cnidaria, Anellida, Mollusca, Crustacea, and Echinodermata, and green algae (Table 2).

During the study period, the release of domestic sewage on site was seen on several occasions. In one sampling, a local resident dumped guts of fish, which attract the black-headed vulture Coragyps atratus (Bechstein, 1793), bird-eating scavengers, always present on site. Fishing (fish, lobsters and octopus) is a common activity here.

\section{Discussion}

Stramonita haemastoma preferred stretches closer to the lower shore, as also observed in previous studies (Rilov et al., 2001; Calil, 2007). This strategy of inhabiting areas with longer submersion times probably minimises the effects of thermal variation and desiccation. The presence of holes and crevices, especially in N1, presumably confers protection from predators. Rilov et al. (2001) also observed higher abundances of S. haemastoma in the lower intertidal zone on the coast of Israel, and attributed this to greater availability of food and shelter. In this study, protection against the physiological stress caused by temperature variations explains why there were fewer individuals of S. haemastoma at the upper level of both sampling sites, where the temperature varies more than at the lower level.

Table 1. Comparisons of the densities of Stramonita haemastoma by analysis of variance (ANOVA), between months, levels, and sampling points on a sandstone bank in Ilhéus, Bahia from October 2007 through September 2008.

\begin{tabular}{lrrrr}
\hline \multicolumn{1}{c}{ Effect } & DF & MS & F & p \\
\hline Months & 11 & 0.3037 & 4.094 & $0.000^{* * *}$ \\
Point & 1 & 1.8492 & 24.928 & $0.000^{* * *}$ \\
Level & 1 & 1.3968 & 18.829 & $0.000^{* * *}$ \\
Month*point & 11 & 0.0918 & 1.238 & $0.265^{\mathrm{ns}}$ \\
Month*level & 11 & 0.2066 & 2.785 & $0.002^{* *}$ \\
Point*level & 1 & 5.8743 & 79.187 & $0.000^{* * *}$ \\
Month*point*level & 11 & 0.1762 & 2.375 & $0.009 * *$ \\
Error & 192 & 0.0742 & & \\
Total & 239 & & 0.000 & \\
\hline
\end{tabular}

ms mean square; $* 5 \%$ probability; $* * 1 \%$ probability; $* * * 0.1 \%$ probability; ns non-significant. 


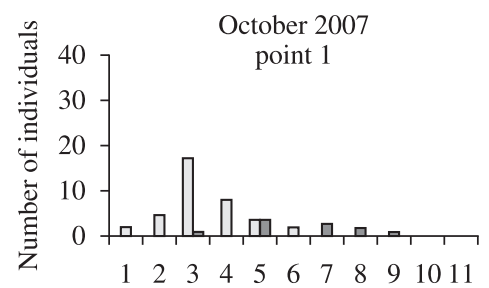

$\square$ Level $1(\mathrm{n}=41) \quad \square \operatorname{Level} 2(\mathrm{n}=11)$
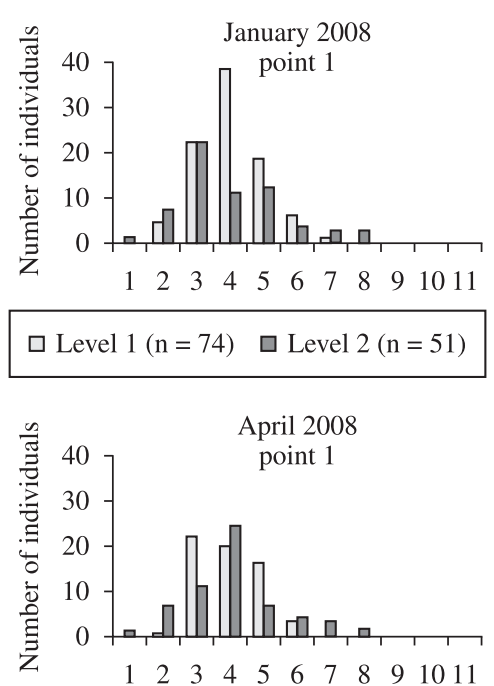

$\begin{array}{llllllllllll}1 & 2 & 3 & 4 & 5 & 6 & 7 & 8 & 9 & 10 & 11\end{array}$
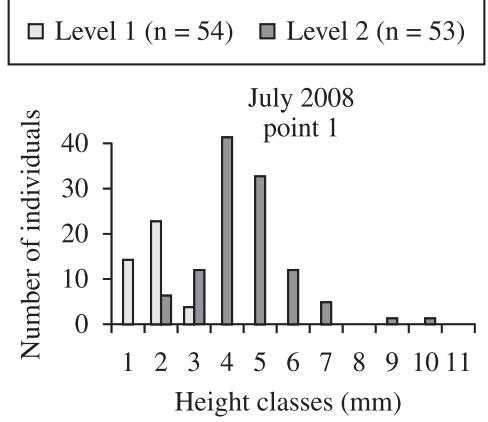

$\square$ Level $1(n=34) \quad \square$ Level $2(n=94)$

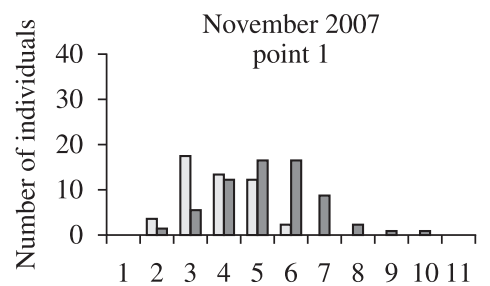

$\square$ Level $1(\mathrm{n}=44) \quad \square$ Level $2(\mathrm{n}=59)$

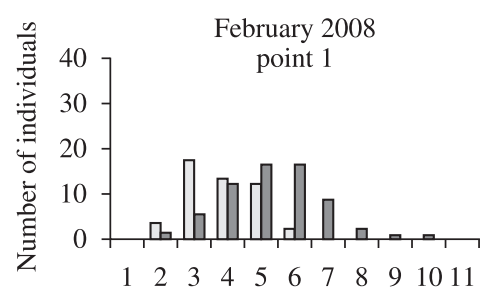

$\square$ Level $1(\mathrm{n}=96) \quad \square$ Level $2(\mathrm{n}=54)$

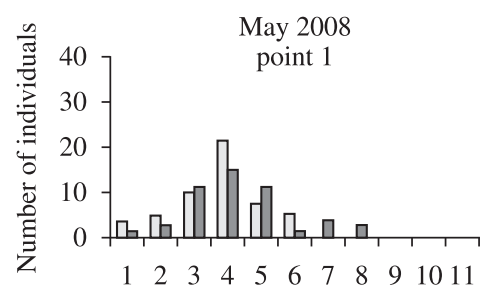

$\square$ Level $1(n=42) \quad \square$ Level $2(n=39)$

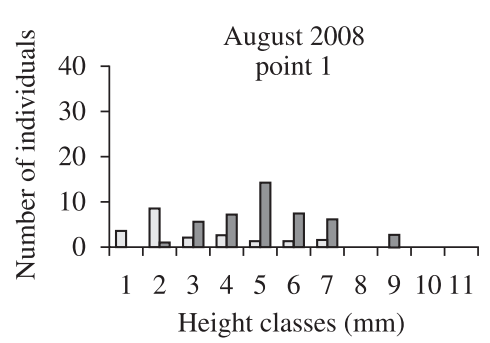

$\square$ Level $1(n=17) \quad \square$ Level $2(n=36)$
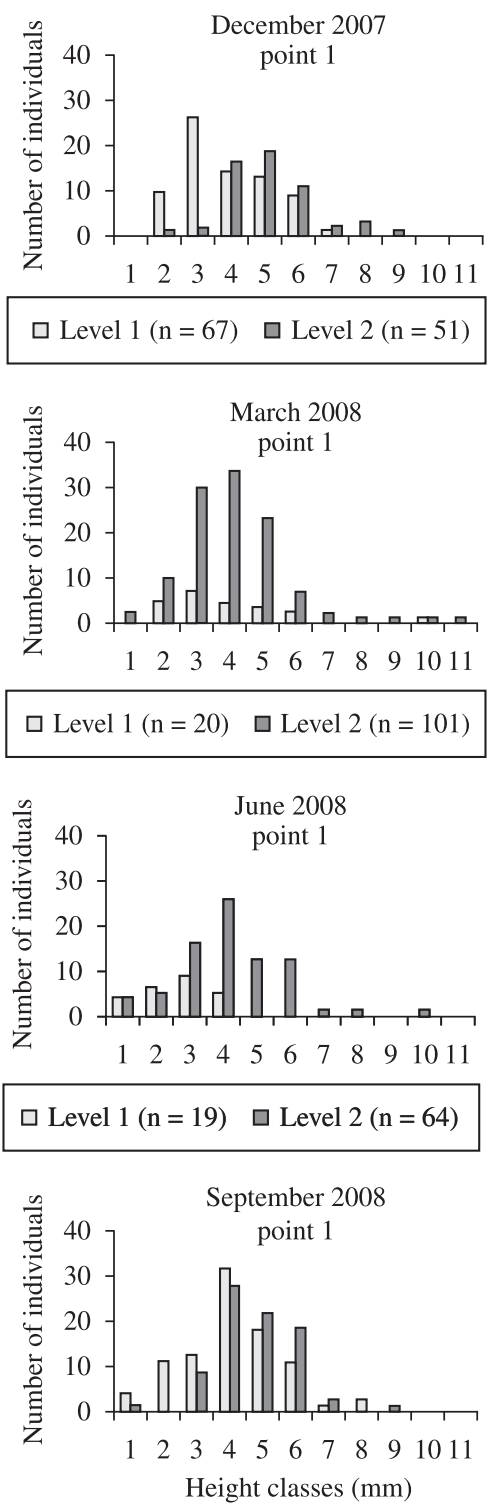

$\square$ Level $1(\mathrm{n}=67) \quad \square$ Level $2(\mathrm{n}=51)$

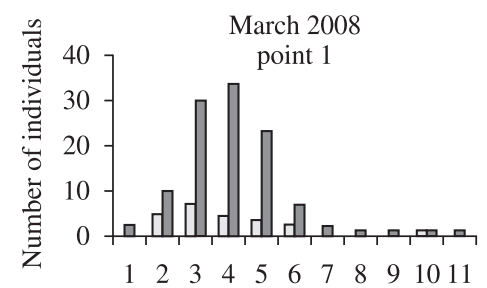

$\square$ Level $1(n=20) \quad \square$ Level $2(n=101)$

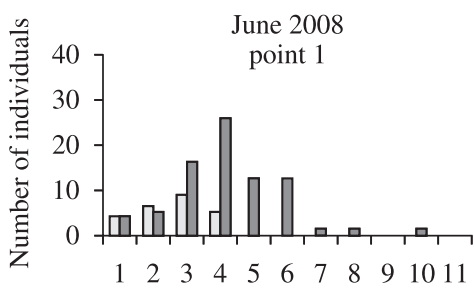

$\square$ Level $1(n=19) \quad \square$ Level $2(n=64)$

$\square$ Level $1(n=75) \quad \square$ Level $2(n=67)$

Figure 3. Size-frequency histograms for Stramonita haemastoma at Point 1 on a sandstone bank in Ilhéus, Bahia, from October 2007 through September 2008.

Similarly, the salinity at point 2 varied more and was higher, indicating greater exposure. Thus, it is possible to associate the difference in the spatial distribution of individuals to the time of exposure to air and the existence of shelter. The slight positive correlation between density and salinity may have been influenced by the high density of S. haemastoma in some periods, as in February 2008. Human disturbance did not appear to affect the densities of S. haemastoma, which were highly abundant in the months with more tourists (December-February). The recruitment observed throughout the years reflects the lack of clearly defined seasons in the region. Notwithstanding, the absence of recruitment in P2 in March 2008 may have been caused by osmotic stress due to the heavy rainfall during this period. Studies in areas with well-defined seasons showed density peaks and breeding periods at different times: density peaks in late autumn and early winter, associated with reproduction in autumn, and greater recruitment in winter were observed on the coast of the state of São Paulo (Marini, 1988; Magalhães, 1988; Duarte, 1990). Breeding peaks were also observed on the coast of the state of Rio de Janeiro during the summer (Lavrado, 1992).

Among the living organisms close to S. haemastoma in this location were Brachidontes solisianus, Acmaea 


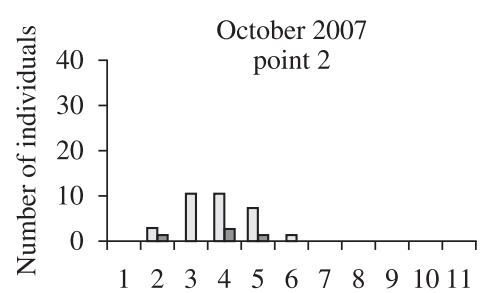

$\square$ Level $1(\mathrm{n}=27) \quad \square$ Level $2(\mathrm{n}=4)$

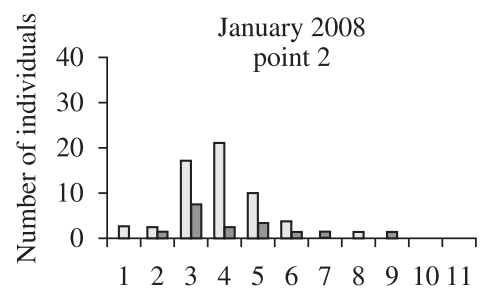

$\square$ Level $1(\mathrm{n}=47) \quad \square \operatorname{Level} 2(\mathrm{n}=15)$

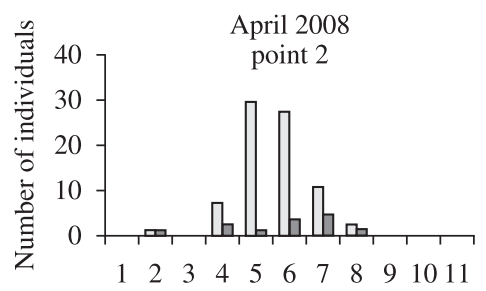

$\square$ Level $1(\mathrm{n}=66) \quad \square$ Level $2(\mathrm{n}=12)$

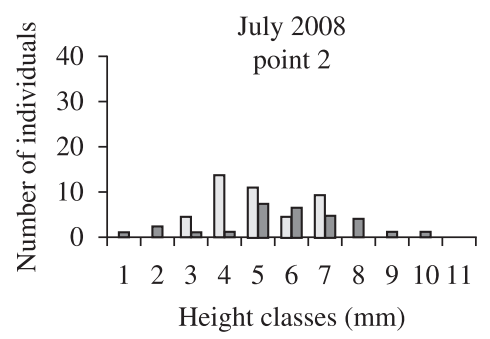

$\square$ Level $1(\mathrm{n}=40) \quad \square \operatorname{Level} 2(\mathrm{n}=26)$

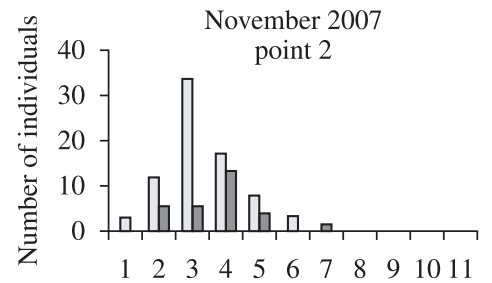

$\square$ Level $1(\mathrm{n}=58) \quad \square \operatorname{Level} 2(\mathrm{n}=22)$
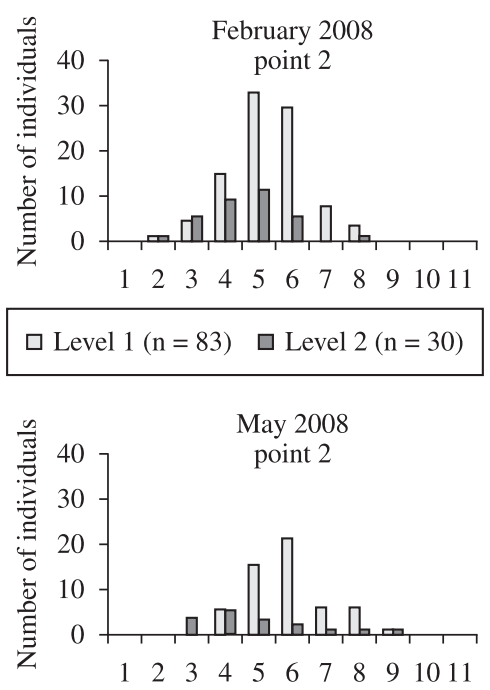

$\square$ Level $1(\mathrm{n}=47) \quad \square \operatorname{Level} 2(\mathrm{n}=16)$

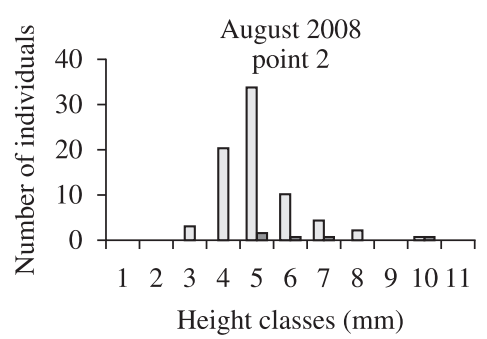

$\square$ Level $1(\mathrm{n}=67) \quad \square \operatorname{Level} 2(\mathrm{n}=5)$
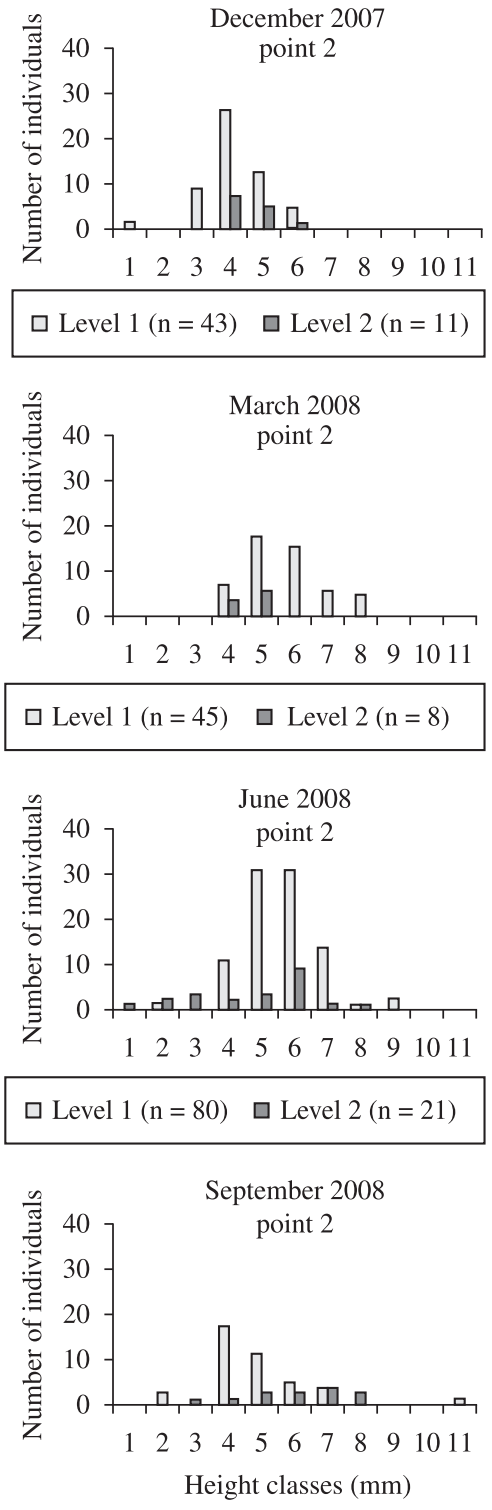

$\square \operatorname{Level} 1(\mathrm{n}=43) \quad \square \operatorname{Level} 2(\mathrm{n}=11)$

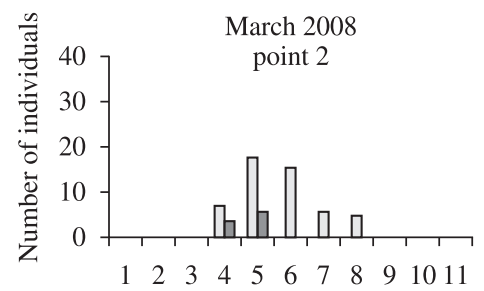

$\square$ Level $1(\mathrm{n}=45) \quad \square \operatorname{Level} 2(\mathrm{n}=8)$

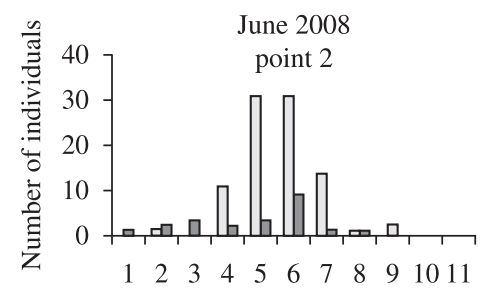

$\square$ Level $1(\mathrm{n}=80) \quad \square \operatorname{Level} 2(\mathrm{n}=21)$

$\square \operatorname{Level} 1(\mathrm{n}=35) \quad \square \operatorname{Level} 2(\mathrm{n}=11)$

Figure 4. Size-frequency histograms for Stramonita haemastoma at Point 2 on a sandstone bank in Ilhéus, Bahia, from October 2007 through September 2008.

subrugosa (Orbigny, 1846), and Chthamalus bisinuatus. These animals are among the main prey of this species (Duarte and Holler, 1987) and their presence probably influences the spatial distribution of this gastropod. As do other predatory gastropods, $S$. haemastoma inhabits environments rich in potential food (Morgan, 1985; Rilov et al., 2001, 2004; Ramirez et al., 2009). The association of several groups of animals with S. haemastoma shows the importance of the species in this environment, since it is an important agent in the food chain in rocky intertidal areas and in cultivated oysters (Butler, 1985; Ferreira and Magalhães, 2004; Nascimento and Pereira, 2004; Watanabe and Young, 2006). Studies on these relationships are needed.
We conclude that recruits as well as other individuals in the population preferentially inhabit places that are submerged for longer periods and provide places for refuge, which decreases the stress from temperature variation and desiccation. In this study it was not possible, from in situ observations, to infer how much human influence is impacting the local biota. Apparently, the biota is not significantly affected in terms of survival, density and growth. According to Coutinho (1999), the release of sewage affects the growth of benthic species, and trash, pollution and overfishing are among the main causes of decline of biological diversity of the benthos. Therefore, it 
Table 2. Inventory of taxa observed near and/or on the surface (epibionts) of Stramonita haemastoma from October 2007 through September 2008 on a sandstone bank in Ilhéus, Bahia.

\begin{tabular}{|c|c|c|c|}
\hline Morphotypes & Phylum & Near S. haemastoma & S. haemastoma epibiont \\
\hline anodosoma sp. (Verrill, 1899) & Cnidaria & $*$ & \\
\hline nurbellarians (flatworm) NI & Platyhelminthes & $*$ & * \\
\hline - Polyplacophora (quíton) NI & Mollusca & & * \\
\hline - Acmaea subrugosa (Orbigny,1846) & Mollusca & $*$ & $*$ \\
\hline Eissurella clenchi (Farfante,1943) & Mollusca & $*$ & \\
\hline $\mathrm{m}$ Littorina ziczac (Gmelin, 1791) & Mollusca & $*$ & $*$ \\
\hline Brachidontes solisianus (Orbigny,1846) & Mollusca & $*$ & $*$ \\
\hline m Ostrea sp. (Linnaeus, 1758) & Mollusca & $*$ & \\
\hline - Chthamalus bisinuatus (Pilsbry,1916) & Crustacea & $*$ & $*$ \\
\hline Echinometra lucunter (Linnaeus,1758) & Echinodermata & $*$ & \\
\hline ص Chlorophyceae & Chlorophyta & $*$ & * \\
\hline
\end{tabular}

$\mathrm{NI}=$ not identified; $\mathbf{a}$ Species present in only one month; $\mathbf{\square}$ Species present in two months; $\mathbf{\square} \boldsymbol{\square}$ Species present in all months.

is necessary that a study on the effect of human disturbance on the biota is done on site.

Acknowledgements - The authors are grateful to CAPES for sponsoring the project, and to UESC for granting a scientific initiation scholarship to the first author.

\section{References}

BUTLER, PA., 1985. Synoptic review of the literature on the southern oyster drill Thais haemastoma floridana. NOAA Technical Report NMFS series, vol. 35, p. 1-12.

CALIL, P., 2007. Tolerância fisiológica ao estresse ambiental de predadores e presas e sua relação com a ocupação de um costão rochoso de zona entremarés. Curitiba: Universidade Federal do Paraná. 119 p. Tese de Doutorado em Zoologia.

COUTINHO, R., 1999. Avaliação e Ações Prioritárias para a Zona Costeira e Marinha. Grupo de ecossistemas: Costões Rochosos. Arraial do Cabo: Programa Nacional da Biodiversidade - PRONABIO. 102 p.

D'ASARO, CN., 1966. The egg capsules, embryogenesis, and early organogenesis of a common oyster predator, Thais haemastoma floridana (Gastropoda: Prosobranchia). Bulletin of Marine Science, vol. 16, no. 4, p. 884-914.

DUARTE, LFL., 1990. Seleção de presas e distribuição do gastrópode Thais haemastoma (L.) no costão da Praia do Rio Verde, Estação Ecológica de Juréia- Itatins, SP. Campinas: Universidade Estadual de Campinas. 106 p. Tese de Doutorado em Biologia.

DUARTE, LFL. and HOLLER, MT., 1987. Estudos preliminares sobre a preferência de Thais haemastoma (L.) (Gastropoda: Prosobranchia) por diferentes espécies de presas. In: Anais do I Simpósio de ecossistemas da costa sul e sudeste brasileira: sintese dos conhecimentos, 1987. Cananéia, São Paulo: Academia de Ciências do Estado de São Paulo. vol. 54, no. 2, p. 192-200.

FERREIRA, JF. and MAGALHÃES, ARM., 2004. Cultivo de Mexilhões. In POLI, CR., POLI, A., ANDREATTA, E. and BELTRAME, E. Aquicultura: Experiências Brasileiras. Florianópolis: Ed. Multitarefa. cap. 9, p. 221-250.
FOSTER, MS., HARROLD, C. and HARDIN, DD., 1991. Point vs. photo quadrat estimates of the cover of sessile marine organisms. Journal of Experimental Marine Biology and Ecology, vol. 146, no. 2, p. 193-203. http://dx.doi.org/10.1016/0022-0981(91)90025-R

LAVRADO, HP., 1992. Seleção de presas pelo gastrópode Thais haemastoma (L.) na região de Arraial do Cabo, RJ. Campinas: Universidade Estadual de Campinas. 104 p. Dissertação de Mestrado em Ecologia.

MABESOONE, JM., 1964. Origin and age of the sandstone reefs of Pernambuco (Northeastern Brazil). Journal of Sedimentary Research, vol. 34, no. 4, p. 715-726.

MAGALHÃES, CA., 1988. Padrões de variação morfológica em Thais haemastoma L. (Gastropoda: Prosobranchia). Campinas: Universidade Estadual de Campinas. 107 p. Dissertação de Mestrado em Biologia.

MARINI, AC., 1988. Estudo de populações polimórficas de Thais haemastoma (Linnaeus, 1767) (Gastropoda: Prosobranchia), do litoral do Estado de São Paulo. Campinas: Universidade Estadual de Campinas. 180 p. Tese de Doutorado em Ecologia.

MORGAN, MJ., 1985. Distribution and dispersion of the predatory intertidal gastropod Morula marginalba. Marine Ecology Progress Series, vol. 22, p. 41-52. http://dx.doi.org/10.3354/meps022041

NASCIMENTO, IA. and PEREIRA, SA., 2004. Cultivo da ostra do mangue - Crassostrea rhizophorae (Guilding, 1828). In POLI, CR., POLI, A., ANDREATTA, E. and BELTRAME, E. Aquicultura: Experiências Brasileiras. Florianópolis: Ed. Multitarefa. cap. 11, p. 267-288.

POLI, CR., 2004. Cultivo de ostras do Pacífico (Crassostrea gigas, 1852). In POLI, CR., POLI, A., ANDREATTA, E. and BELTRAME, E. Aquicultura: Experiências Brasileiras. Florianópolis: Ed. Multitarefa. cap. 10, p. 251-266.

RAMÍREZ, R.; TUYA, F. and HAROUN, RJ., 2009. Spatial patterns in the population structure of the whelk Stramonita haemastoma (Linnaeus, 1766) (Gastropoda: Muricidae) in the Canarian Archipelago (eastern Atlantic). Scientia Marina, vol. 73, no. 3, p. 431-437. http://dx.doi.org/10.3989/scimar.2009.73n3431

RILOV, G., BENAYAHU, Y. and GASITH, A., 2001. Low abundance and skewed population structure of the whelk Stramonita haemastoma along the israeli mediterranean coast. Marine Ecology 
Progress Series, vol. 218, p. 189-202. http://dx.doi.org/10.3354/ meps218189

-, 2004. Life on the edge: do biomechanical and behavioural adaptations to wave-exposure correlate with habitat partitioning in predatory whelks. Marine Ecology Progress Series, vol. 282, p. 193-204. http://dx.doi.org/10.3354/meps282193

RIOS, E., 2009. Compendium of Brazilian Sea Shells. Rio Grande: Ed. Evangraf. 668 p.

ROLLER, RA. and STICKLE, WB., 1988. Intracapsular development of Thais haemastoma canaliculata (Gray) (Prosobranchia: Muricidae) under laboratory conditions. American Malacological Bulletin, vol. 6, no. 2, p. 189-197.
SAFRIEL, UN., GILBOA, A. and FELSENBURG, T. 1980. Distribution of rocky intertidal mussels in the Red Sea coasts of Sinai, the Suez Canal, and the Mediterranean coast of Israel, with special reference to recent colonizer. Journal of Biogeography, vol. 7, p. 39-62. http://dx.doi.org/10.2307/2844546

THOMÉ, WJ., BERGONCI, PEA. and GUACIRA, MG., 2004. As conchas das nossas praias. Pelotas: Ed. Useb.48 p.

WATANABE, JT., YOUNG, CM., 2006. Feeding habits and phenotypic changes in proboscis length in the southern oyster drill, Stramonita haemastoma (Gastropoda: Muricidae), on Florida sabellariid worm reefs. Marine Biology, vol. 148, p. 1021-1029. http://dx.doi.org/10.1007/s00227-005-0152-9 
